\title{
Misbeliefs of an Ideal World in Amish Tripathi's Immortals of Meluha
}

\author{
R. Manikandan ${ }^{a}$, and Dr. M. R. Bindu ${ }^{b}$ \\ Assistant Professor of English \& Research Scholar, \\ Veltech Rangarajan Dr.Sagunthala R\&D Institute of Science \& Technology \\ Outer Ring Road, Avadi, Chennai- 600062 \\ bProfessor \& Head \\ Department of English \\ Veltech Rangarajan Dr.Sagunthala R\&D Institute of Science \& Technology \\ Outer Ring Road, Avadi, Chennai- 600062
}

Article History: Received: 11 January 2021; Accepted: 27 February 2021; Published online: 5 April 2021

\begin{abstract}
Amish Tripathi, the bored banker-turned-happy-author of Indian writing in English, has written seven novels till in two series. His novels are famous for his recreation of Indian Hindu mythology and have been sold over seven million copies. The first series Shiva Trilogy deals with Shiva Puranas whereas the second series Ramchandra Series is a fantasy retelling The Ramayana. The concept of Ideal society has been represented by several authors starting from Plato's Republic to Ursula Le Guin's The Dispossessed. But, Amish Tripathi is one of the few authors who has created an Ideal world only to show that there can never be an ideal world.
\end{abstract}

Keywords: Ideal World, Meluhans, Law of Nature, Untouchability, Utopia.

\section{Introduction}

The authors who dreamt of Utopian society are many including Plato of Ancient Greek Literature, and Thomas More, Francis Bacon, H G Wells, William Morris, the American Psychologist B.F. Skinner to name a few. Though each of them has decided to create better society, their means to achieve their goals differ. As a result of witnessing Protestants being killed and jailed during his time, Thomas More in his book, Utopia, opines that people are free to choose their own religion. Francis Bacon provides utmost importance to educating people through Salomon House - an ideal college where people stay and learn philosophies and Sciences to better society - in his incomplete utopian novel New Atlantis. Twentieth century English writer and philosopher, Aldous Huxley creates utopian society in novel Island where people focus on the present, believe in peaceful living, long for intellectual and spiritual pursuits.

"There is a tyranny in the womb of every utopia" (10), famously states the French economist and futurist in his book Sovereignty: An Inquiry into the Political Good. It is highly valid because hypocrisy has always been present and humanity is deficient in almost all the utopian novels over the years; Plato advises eugenics, a control over genetic reproduction, in Republic, and Aldous Huxley advocates, in his novel Island, a dangerous spiritual climbing - a few characters in the novel are even killed during this act- to the top of particular mountain in the name of attaining spiritual value.

Indian fiction writers who write in English have also tried their hand in creating utopian societies, for instance Salmon Rushdie's Grimus and Anu Manjumdar's Auroville are two prime examples. Amish Tripathi, who is hailed as the Paulo Coelho of the east by Business Today, has become a household name in every literature lover's houses in India after the publication of his Shiva Trilogy. His unique way of mixing mythology with literature has received immense praise from literary critic and audience alike.

Amish Tripathi creates a near perfect world in the first part of Trilogy, The Immortals of Meluha; in fact, in the words of Nandi, one of the major characters of the novel, Meluha is "the richest and most powerful empire in India" (2). The immediate look of Kashmir makes Shiva, the protagonist of the novel, release a huge sigh of relief for he believes he has reached a better, safer place than his homeland Kailash. Though Kashmir's landscape is aweinspiring, the city of Srinagar reflects Meluhans obsession with cleanliness. "Cleanliness was next to godliness. We can no more gain God's blessings with an unclean body than with an unclean mind. A clean body cannot reside in an unclean city", stated MK Gandhi. Meluhans, as many ideal societies believe, consider being clean is a sign of spiritual purity and goodness It becomes a major trait of Meluhans throughout the novel. Their mania for hygiene goes to an intimidating extend when their divine Somras produced and used

...All Meluhans are taught about two things from their young age - water and hygiene. Water is the cleanest absorber of the effluents that the Somras generates and excretes as toxins. Meluhans are taught to drink gallons of water. And everything that can be washed, should be washed! All ablutions are done in a specific rooms and underground drains then carry the waste out of the city. (135) 
But, Meluhans' cleanliness does not come without its fair share of wastages. In order to prepare their divine drink Somras, they collect water from Saraswati river using canals and store in a place which they call it a Sagar, an ocean. Besides, they must use the live Sanjeevini tree mix to work for which they have to constantly churn the crushed branches of it with Sarasawati water to make it work. "Man is the most insane species. He worships an invisible God and destroys a visible Nature", stated Canadian Astrophysicist Hubert Reeves. In the name of purifying Meluha - which, they think, is a major aspect of an ideal society - the scientists cut the trees and use gallons of water from Saraswati river without even realizing the river is dying and many other empires which depend on Saraswati will have troubles leading their normal life. On the other hand, Meluhans, particularly their King Daksha is expecting Shiva, the designated savior, to resolve all the problems. Here, it is evident, an Ideal society, often, tend to disturb harmony between nature and human at the hand of perfection.

Meluha has Vikarmas, a group of people who are considered untouchables because of the sins of their previous birth - they cannot marry and are not allowed to touch any person other than their community. Such acts are crime and contamination of Meluhans ideal way of living. In one of his treatises, Dr. Ambedkar states "If I am equal before God, why am I not equal on earth? Manu was probably terrified by this question". But, none of the Meluhan is protesting this cruel act in the novel and, in fact the Vikarmas believe it is really their fault. The fear of disrupting the order of their society, makes Meluhans inhumane and work on superstitions. Thus, the real need for a utopian society where equality should be the uppermost priority turns into delusions in Meluha, where equality has no place in law book. Meluhans' divine drink Somras is an anti-aging medicine which besides postponing their death gives them comfort as if they are in the prime of their youth, as emperor Daksha puts it Somras, the drink of the Gods...was invented by many thousand years ago by one of the greatest Indian scientists ever lived. His name was Lord Brahma... he did not give Somras freely to anyone... after conducting a rigorous country-wide survey, he chose a select group of adolescent boys of impeccable character-one from each of seven regions of ancient India. (99)

According to Lord Brahma, Somras consumption requires several strict rules to be fulfilled and, the basic purpose to serve Somras is to serve for the betterment of society. But, the emperor Daksha states that Lord Ram, who created the near perfect empire, Meluha, believes every law is finite and once the time is over it becomes against the law of nature. If someone goes by the statement, they tend to believe that Meluhans are old-fashioned, because they have forgotten the concept of Somras is out-of-date and it has already become dangerous to humankind. "I cannot help thinking that the menace of Hell makes as many devils as the severe penal codes of inhuman humanity make villains" opined famous English poet, Lord Byron. To validate the statement, there are several evidences. The intake of Somaras has its fair share of problems-when women take this, there is a huge chance for them give birth to still born children or children with deformities. Meluhans consider people with deformities as vikarmas and put the blame, for such deformities, on the sins of their previous birth. The Nagas, who are deformed, take oath to destroy Meluha because of inhuman acts committed to them. Here it is clearly proven, that when a society goes against the Law of Nature will be certainly doomed. Meluhans way of taking Somras for postponing their death is against the law of nature.

\section{Conclusion}

Thus, a detailed analysis of The Immortals of Mehula clearly indicates that it is highly impossible to create an Ideal Society, because to be Ideal and Perfect is being inhuman to the other societies and against the laws of nature. The very idea of perfect society destroys the harmony of nature and human. Meluhans, indeed, seem to be a perfect society but it has several issues - they destroy Nature, they make humans Immortal, they have untouchabilitywhich signpost that they have a long way to go before they become Ideal society.

\section{References:}

1. Tripathi, Amish. The Immortals of Meluha. Chennai: Westland Press, 2010. Print.

2. Jouvenel, De. Betrand. Sovereignty: An enquiry into the Political Good. Indiana: Liberity Fund, Inc. 1998.

3. Rusdie, Salmon. Grimus, New Delhi: Random House Trade Paperbacks, 2003. https://en.wikipedia.org/wiki/Republic_(Plato) https://www.reddit.com/r/quotes/comments/250rv7/man_is_the_most_insane_species_he_worships_an/

4. https://blackleaderanalysis.com/2018/04/14/who-were-the-untouchables/ https://en.wikipedia.org/wiki/The_Dispossessed

5. https://en.wikipedia.org/wiki/Utopia_(book) https://en.wikipedia.org/wiki/New_Atlantis

6. https://quotefancy.com/quote/854002/Lord-Byron-I-cannot-help-thinking-that-the-menace- of-Hellmakes-as-many-devils-as-the

7. https://www.mkgandhi.org/articles/gandhian-thoughts-about-cleanliness.html 